UC-NRLF

1651

A. 4

Biology
B 4587373

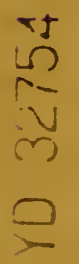




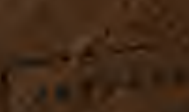

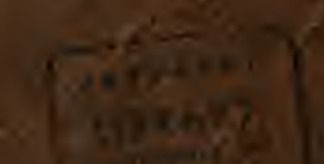

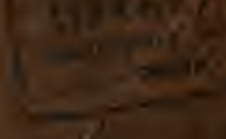

29 



\section{NARRATIVE OF A TRIP TO THE BAHAIIAS.}

B Y

GLOVER M. ALLEN

AND

THOMAS BARBOUR. 




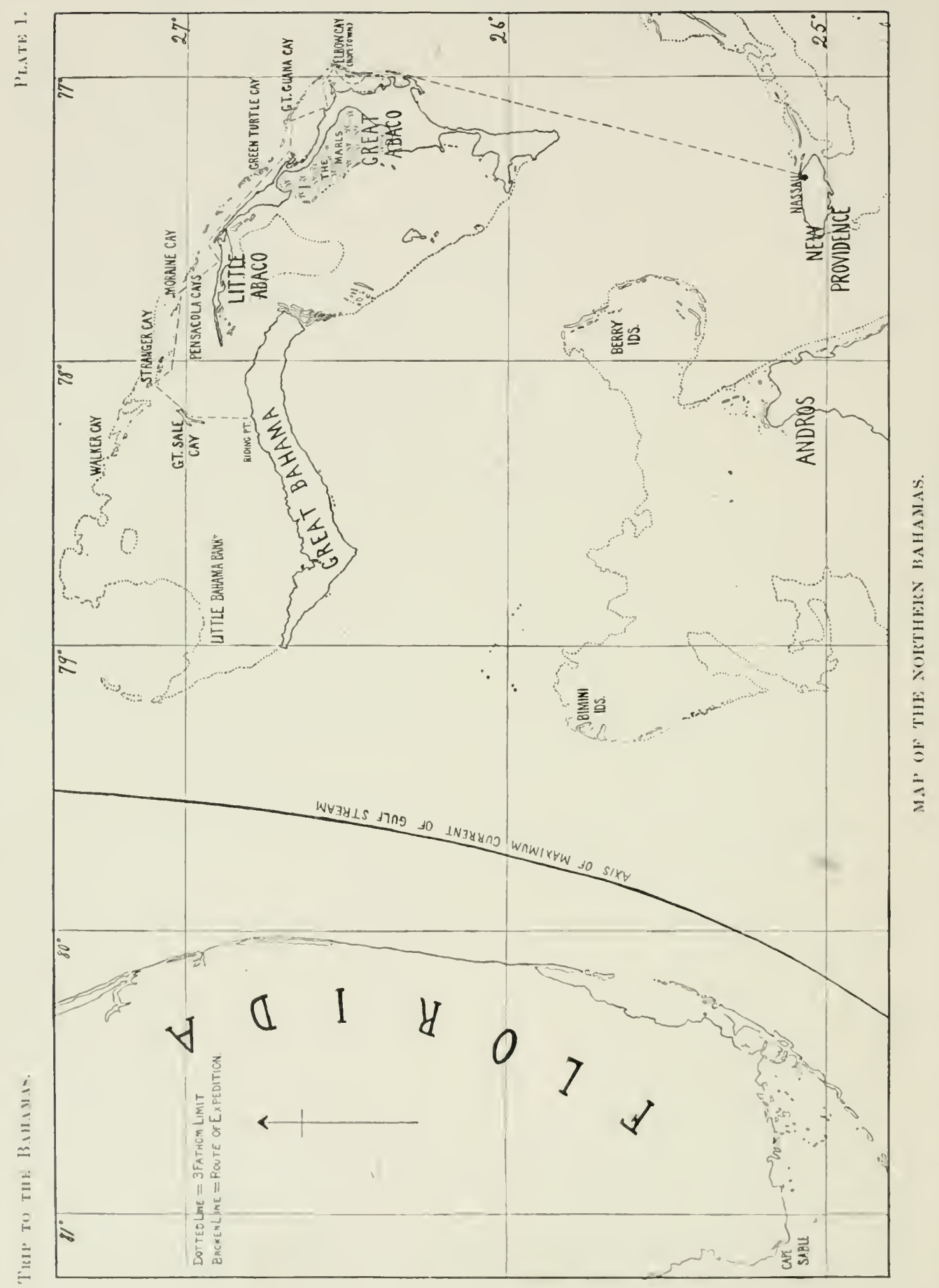




\section{NARRATIVE OF A TRIP TO THE BAHAMAS.}

BY GLOVER M. ALLEN ANI THOMLAS BARBOUR.

Thus is the first of a series of short papers on the flora and fauna of the Bahamas, the results of a tril, made by us during the early part of the smmmer of 1904 , with Mr. Owen Bryant. We visited a number of the northern islands of the Bahama gromp to make such collections as were possible in the limited time before the hurricane season.

These subtropical islands are easily accessil,le to naturalists from the continent, and although considerable work has been done among them, much ret remains for future exploration. Most visitors to the islands go in the winter season since the heat of summer is extremely oppressive. Yet we found it possible to be comfortable and at the same time to make valuable collections. The present account of our expertition is offered in the hope that it may be of use to other investigators who contemplate similar work among the Bahamas. Further rejorts, baser on studies of the material collecter, are in preparation, and will appear as occasion mas offer.

The party left New York on the S. S. "Orizaba," sailing June 24th, for Nassau. About daybreak of June 2sth we sighterl New Providence Island, and a little later, on landing, found comfortable quarters at the Clifton llomse, the only hotel open during the smmmer season. We spent the few following days until July od in collecting in the vicinity of the city of Nassau. A carriage and driver may he had for 70 cents an hour and it is thus an easy matter to make excursions in several directions from the city proper, back into the country of the interior of the island. The gardens and cultivaterl gromuls in the city itself, however, are rich in insects of many kinds as well as other indigenous animals.

On the advice of Mr. Ronald Young we chartered the sixty ton schooner "Wm. 11. Alhury" (Capt. Daniel Riussell) and found her toleralhly well alapterl to on needs. She was tifty-nine feet over all and hrew about six feet of water. She was roomy and most seaworthy; but had more of the space been cabin instead of hold we should have been suited better. W' cannot too strongly adrise 
fersoms who contemplate a visit to the bahamas in summer to make sure of an awning for the derek and an arleywate supply of mosingito netting. ()ils of eitronella and gennymal mixen in explul parts will also be foumd very useful in helping to keep off the gnats, stinging flies, and mosplutoes. Which are exeessively abumbant in some localities.

Our rew comsisted of captain, mate, conk, and three ordinary seamen, with several extra men pirked uj along our ronte as acasion respurerl. It is wise to have om boaml ratles more men than are likely to be neeted as phesically they are far from strong. This applies esprecially to the white inhalitants of Alaton: for a diet of fruit, salt meat, and rice has left them pron workers eren when they are aroused from their tropical lethargeg. It is possible that in many respects a negro crew womld he more usetul.

A few womls as rexamls food are not out of place in this connections. Manufacturesl iee, which may le ohtainesl at Nissall for a

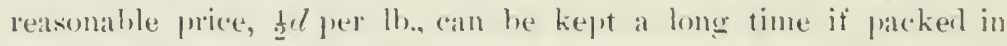
large chunks with a theral quantity of barley shureks. Coon rain water may be obtained at Nassan. One shombl be careful not to rely on the varions "wells," really holes in the ground where the surface water collects, for the water from these has a most mulleasant taste and is teeming with animal life, moleh of it quite visible to the naked eye. We foumb lime juice a most pleasant andition to the water and always weed it. Limes maly le ohtained at most of the settlements for $6, d$ per humberl. Fresh meat cammot lie kejt even if it is obtamable. The native leeef and mutom are vile and mothing else ean be olstinned in simmer. On the other hand, the fish which alouml alout all the reefis and in the chammels are reery gum indeed. We might mention esperially the grompere the varions

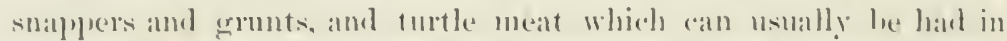

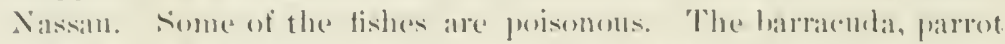

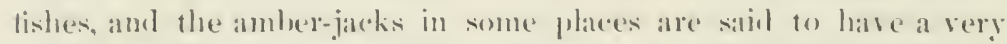
hitter taste and to anse serere sickness. A good general rute is to areisl the bright, showy lishes, although exceptions may often be made. In Nassitu camnerl goods may he whtained lut in quality they are far inferior to those which might he hromglot from the North.

After frovisioning onl craft and getting our aplatatus safely stowerl, "re set sail at a r. s., of July 2, for Ilopetown, Ellow Car, 
9s miles north of New l'rovidence. This passage was rather rough, owing to a heary sollest wind and we were all glad to cross Little IIarbor Bar and to enter the still water behind the ontlying fringe of cays off Great Abaco. Ilopetown is one of the few white settlements in the bahamas and hoasts alout 1000 inhabitants. Here is the large lighthonse that warns mariners from the drearled Ellow Reef, which in the old lays was such a profitable collecting ground for the wreckers.

For two days we did shore-collecting here but did not find it particularly jroductive. The rocks along the shore yielderl a considerable nmmber of shells and we fomm large colonies of the rockboring barnacle, Lithotrya. A good deal of collecting we did in five or six feet of water, using a waterglass to examine the hottom. The abundance of sharks was somewhat of a llawluck. Nlthough we were assured by the natives that these were rery timirl yet they sometimes cante within 1.j feet of us. Thongh we did not see any very large ones on the Abaco sille of Ellow Cay, we did see sereral monsters in the surf on the ocean side. After two days spent here we went to Marsh Harbor on the "mainland" of Great Alaco, and from this point we made several excursions among the intricate waterways of "The Marks." Ilere we saw one splenclid hand of fifty-four flamingoes as well as a few scattered indivicluals. Formerly these hirds nester here in great flocks lont owing to the great destruction of the eggs and young hims by the people of Marsh Ilarbor, a mere remnant now remains. Their nesting site has not been discovered for two years and if it can le kejt hidlen for a few years more their number may increase. In the bahamas the craving of the people for fresh meat can only he satistierl by using gulls, terns, cormorants, and flamingoes for fool. I crying need of the islands is a good set of game laws for none whatever exist to-day. We were forced on sereral occasions to try these varioms birch as foor and cannot recomment persons to rely on them. The wild pigeon which occurs in thomsands on some of the cays is, howerer, delicions.

Alout noon of July sth we set out for Great Guana Cay, where we spent several diys in shore-collecting and drerlging in Guana Cay channel. Of omr oredging apparatus we purpose to speak later. We male sood use here of the snapnet in collecting small reef fishes, baiting and setting it in from $10-30$ feet of water and 
watching it with a waterglass, until, when a number of specimens were busy about the hat, it was elosed with a jerk of the line and hamled to the surface.

At the kind invitation of Mr. Arthm H. Niela, of the Nisal Fiber Company, we spent two most pleasant days at the extensive plantation on Little Ahaco. Here we had an oppurtunity to olserve the preparation of the liber and to collect a number of lime animals and jlants in the vicinity of the village of cooling 'Temper. Not far away, near the village of 'Tar liottom is a lange, ahmost eireular lake, of great dejth whose water, fresh at the surface, is salty at a slight distance down. There is supposed to be some subtermean connection with the seat for it is not momsual to find large sea lish and sometimes turtles in the lake.

Leaving little Abaco on .July 11 th, after making a short stop near Cedar Ilarhor to examine a series of caves, we stood off for the Pensacola cays. Hlere we spent several days in dredging am shore-collecting. We made doraine Cay our headyuarters and from here we male several short excursoms to nejghbring islets. This island is at great roosting place for the pigeons and numbers also nest among the bushes. They feed during the diy on the nearly islands and return to Moraine Cay to spend the night. This bird is the eom-

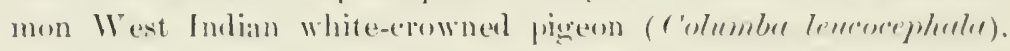

Before 5.1 .1$. of the 1 th we were olf for stranger (ays. The wiml fell to an almost dearl calm and hefore long a territie tropical thunder spuall was on us. The rain came lown in blimbling sheets and the wind blew a gale. Just as the storm ahated we male ont two waterspouts some miles to seatwat. 'The wiml held favoralite and as we lan along hefore it we passed fish Cays where a great multitule of sea birts ruse and circled about shrilly soreaming. This is a fororite plate for the spongers to "exger 11 " before a cruise: and it was erident that the bivls had no lowe for intmolers. Alumt the midhle of the aftermon we arrived at strangere Cay, where owing to extemsive slobals we hat to lie oft allent half a mile from shore. Ileme there was al desertert homse, the only sign of human habitation since laving little Abateo. ()n this

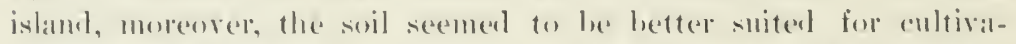
tion than the meager bit of simd on most of the onher * leeswarl

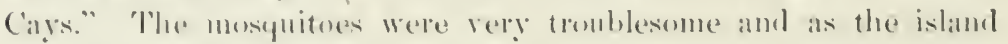
was not a paticularly rich eollading tield we were not sorry when 
at noon of the 15 th we turned sonth and mate for Great Sale Cay. We might ard that on the simd thats we had good sport from our small boat spearing the large "sting-a-rees," giant skate-like creatures. The way in which they rusher the hoat off, often rising from the water and flapping their great wing-like fins, adder much to the excitement. When finally killed and hoisterl ahoarl the schooner they were useful as shark hait.

At Great Sale Cay we met several hoats, the last of the sponging schooners, homeward bound. All the crews boarled us, asking what we were doing and where we were going. Perhaps it was their advice that made our erew so shy of aproaching the shore of Great Bahama; for the following morning after our visitors had left, the captain and mate asked us to omit this stage of om trip. We insisted, however, and after some excitement incidental to the harpooning of a large leopard shark (Cruleocerdo tigrimm) from our deck, set sail for an anchorage some distance off liding Point, "Grand Bah'ma." The bottom all about here is very hard and the on-shore winds roll np heayy seas, so that we dared not run within several miles of the outlying flats. Only one of our crew had ever been here before; for this shore, asile from its other mpleasant features, is not a profitable sponging ground. From our anchorage it was a matter of sereral homrs of alternately sailing and hauling our small boats over series of shoals and mud thats, before reaching shore. Even here a long stretch of excessively ditticult walking lay between us and tree growth. The entire surface of the ground, except where it was covered with a layer of fine, sticky mud from an inch to sereral feet in depth, was curiously eroded, and everywhere shary points of limestone rock and ridges keen and hard as knife blades rendered our progress slow and painful. Once among the trees, conditions were even more unfavorable for an extended survey of the land, since the ground was everywhere covered with a thick tangle perhaps six feet high of the thorniest of xerophytes.

After learing Great Bahama, where we had heen able to spend hut a couple of days, we retraced our course, stopling only at Marsh IIarbor, IIopetown, and sweeting's Village. 'This return passage was rendered more difficult by the increasing number of squalls, now of daily occurrence, and the intervening periorls of calm weather. Noreover, our stores had become very low, as unforeseen delays prevented our replenishing them at Hopetown, about the only place where food could be obtainerl. 
Near sweeting's Village, on July 20,kl, we went alshore on " the main" in orler to visit the eal es at IInrricane Hole, - one of which bat been inhahitem ton many years by a large colong of bats ( $/$ hyl-

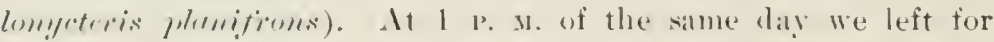
Nassalu. The wiml was shifty and sometimes almost deal ahead, and it was not until midnight that we passed the light at IIole-in-

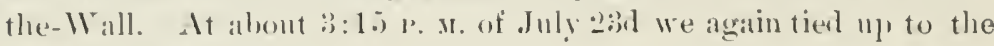
yllay alt Natssill.

In some of the cuts aplended, are shown the main types of vege-

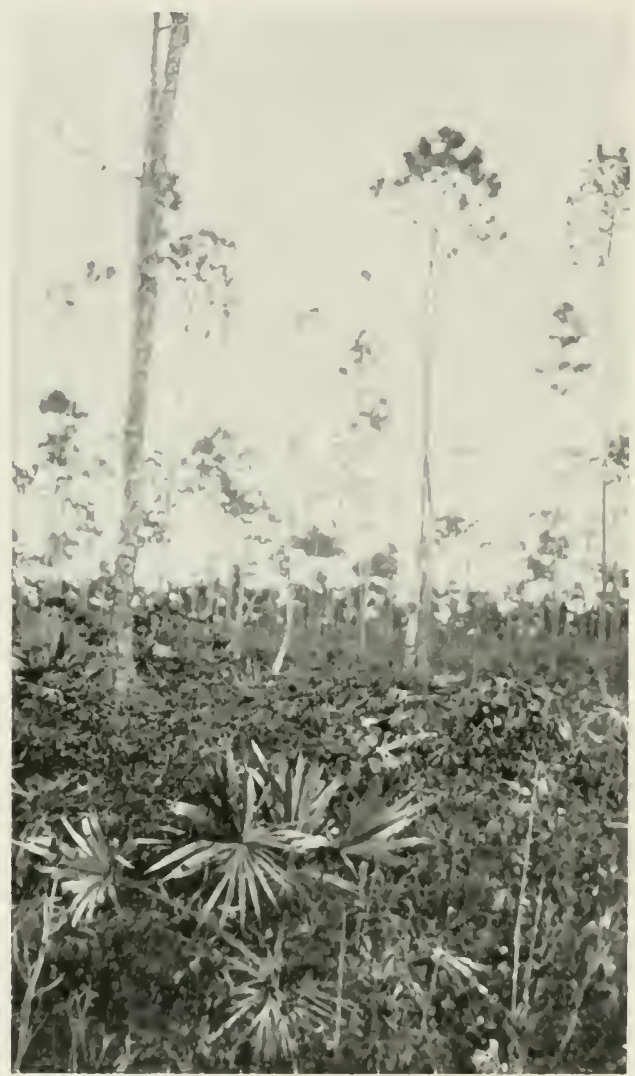

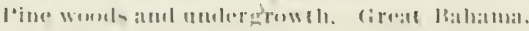
tation among the Baliamas. The text fignre illustrates the open pine noorls with tanglerl untergrowtl, characteristic of the large islands, as Great Bahama, (ireat Alsaeo, little Ahareo, and New Provirlence. The ontskirts of these main islants are frepuently hordered with low mangrove strallis, or more open stretches (pl. 2. fig. 1) where the hrokens surfiate of the limestone of fers litfle foutbold for any but stragyling lushes. 'Tlue wirket-like metherl in which the mangrove hral 12 ches gatow is well show

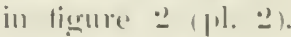
sitill another tripe of vegretation is seen antomg the algs. This is a tangle of palmettens 
of sereral species, bushes, and rines, and is known as "copplet" (j)l. : tig. :3). On many of the islands cocoannt palms are introdnced and thrive well. liogal palms, date pahns, pawpaws, hreadfruit and almonl trees are also commonly coltivated at Nassan as well as other tropical rarieties. (Luantities of pineapples are grown, but the soil is so pror that it is soon exhansted.

The land fammi is in a large measure made "1] of West Indian species, and in part also of continental species, while a few forms are wide ranging. Mr. F. M. Chapman has reviewed the origin of the Bahaman avifanna in an important paper in the American Natmalist several years ago (vol. $25,1891,1,528-539$ ). The indigenous mammals of the Bahamas are few. A racoon (Proryon mongmerli) is foumd on New Providence Island and is distinct from the mainland variety. Several species of lats also ocem. A species of Capromys is found on the Plana Cays, in the southern part of the group. We were informed hy Mr. Robert Johnstone, of Nassan, that a manatee was eaptured at the Bimini Islands about a year or more since. The animal was killed hy some negroes abont the time of one of Mr. Johnstone's visits as circuit magistrate.

Through the kindness of Mr. Alexander Agassiz we were permitterl to make use of a hand-winch and 350 fathoms of steel cahle. By means of this apparatus and a twenty-inch Blake dredge or four foot tangle-har we made a mmber of hanls along our ronte. Dredging from a saling ressel is lifficult work at any time but it is particularly so when the weather conditions are unfarorahle. We set om winch mp on the starhoard sirle of the schooner, rather far aft. The cable we ran forward and throngh a set of blocks made fast to a boom on the foremast. This extra hoom was rigged moler the regular foreboom. In this way we were enabled to drerlge over the bean, a method which is far more convenient than drerlging over the stern. To the end of this boom was attached one of the shipis runners, which served to hoist the load on deck, and a guy, which was carried forwarl and male fast to one of the cat-hearls. This arrangement is shown in tig. 4 (jl. 3) which gives one an idea of how the whole aplaratus appeared from the bow. With this apparatus we male a number of snceesstul lamls in from three to twenty fathoms. Lint in deeper water, say fifty fathoms, the work hecomes very difficult as well as precarions. The lack of a spring accumulator and the character of the lottom were our main dif- 
ficulties, and caused us the loss of several dredges. We were also unfortunate in having heary syualls (ome mp ahnost every time we ran out to sea to make the leeper lamls.

l'ersons who contemplate dredging in the bahamas shomld apply to the Colonial secetary for a permit, preferably though their Consul, as drerlgeing is forbidren by law owing to the damage to the spronge industry.

Several interesting species of fishes were taken while dredging off the island of Abaw, among which mat be mentioned the rare eel, sphlongelnomblus angmiformis. Youmg Monocanthi were taken in every haul on grassy bottom; and in rather coarse white sand we obtained Asymmetion lucreycummen.

We may fittingly close this lnief sketch with a few remarks on the general combitions of several of the more important islands which we risited. The "out islands" are strangely little known even to the people of $\mathrm{N}$ assan, 10 sily nothing of the average Ameriean. Much of our information has heen obtained from the Anmual lejort for 1902. hy rir (r. 'T. Carter lately of the Bahamals and now Governor of Barbatoes. This is illustrated and is far more interesting than the areage blue-book; in fact erery person who contemplates a visit to the bahamas shomld certainly send for a copy and read it carefully. We will take mp the several islands here in the arler in which we visiterl them and rematr shortly upon each.

New Provilence, the most important island in the gromp, contains the eapital, Natssan. The island is alont twenty miles long and nine miles boald. The popmlation of the whole island (1901) is ahout 12,500 persons. The rity is now freplently visited in the winter season and the island is therefore well known to Americans.

Alateo and the Nortlem (ays: The main islands are Great and Little Abace: aceording to Gor. Sir G. 'T. Carter they have an area

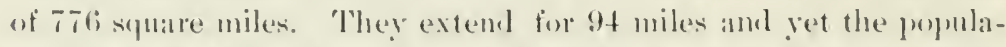
tion is only 38300 people, and is decreasing. The principal settle-

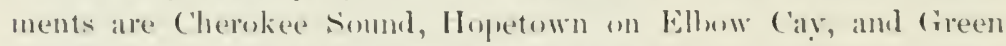
'Turte (ay. The first of these seftements is a mele fishong village;

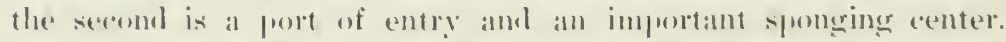

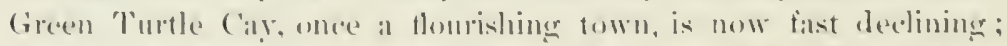

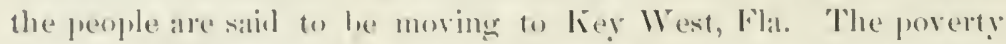

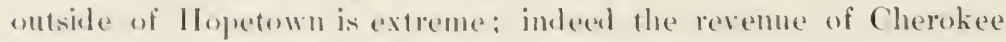
sound in lagl is stafed fo have leeen $f t 7 . s$. There is some valu- 
able timber on Abaco and a concession has been granted to exploit the forests. A large amount of sisal is grown on little Abaco and a lesser amount ahout Hopetown. Off the Abaco coast to the Matanilla reefs (lat. $27^{\circ} 23^{\prime} \mathrm{N}$., long. $78^{\circ} 50^{\prime} \mathrm{W}^{\prime}$.) extends an unbroken fringe of cays and reefs, once the abode of the unscrupulous wreckers, who now have little to do as their favorite trade has been destroyed by the lighthouse at Elbow Cay.

Great Bahama: This island contains 430 square miles, is 66 miles long and from 5 to 12 miles wirle. 'The popmlation is stated to be 1780 people. The inhahitants are mainly engaged in sponging and fishing. The character of the land seems particularly untit for agriculture or cattle raising.

The people of these northern islands do not take kindly to the mild vocations now open to them. Their ancestors have for generations been very little hetter than pirates; and as they often told us, they consiler the lighthouses a curse instead of a mark of progressive development.

The writers returned to New York arriving about the first of August, but Mr. Bryant remained behind for a visit to Andros Island. Ile went to Mangrove Cay and there made some most interesting collections, particularly of rejtiles and molluscs.

Andros Island is the largest of all the bahamas being really a more or less connected aggregate of many islands, the whole land mass having an area of about 1600 square miles. As only part of this has been explored it still offers a fruitful field for biological work. The entire population is only a little over 5000 persons. This island is the only one with running fresh water hut unfortunately the stream is useless to the settlers as it is situated in swamy and uninhabitable land. There is vahable timber on Andros as well as on some of the other islands, lont as there are no roads nor good harbors it cannot be worked successfully. The colony is so poor that no improvements can be made and consequently there is little or no encouragement for settlers to emigrate thither.

The pleasure of our stay in Nassau was largely due to the very kind attention shown us by the American Consul, Mr. Julian P'otter, and by Mr. Young, chairman of the Sponge Fisheries Board ; both of these gentlemen assisted us in many ways. 'T'o the Administrator, Colonial Secretary, and Executive Council of the Bahamas our thanks are due for permission to import and use our dredge within 
the juristiction of the anomy. Finally, we have the pleasure of acknowledging our deep obligation to liobert Johustone, Escy., the colonial Magistrate, for his many kindnesses and for his grenerous hospitality. 


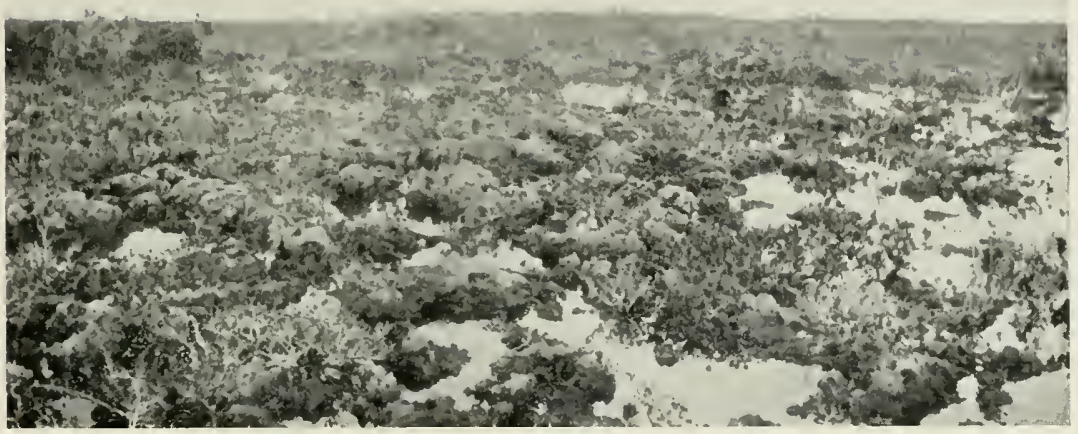

FI(, 1.-ER()IEI) IIMESTONE AIONG SHORE, IIREAT BAHAMA.

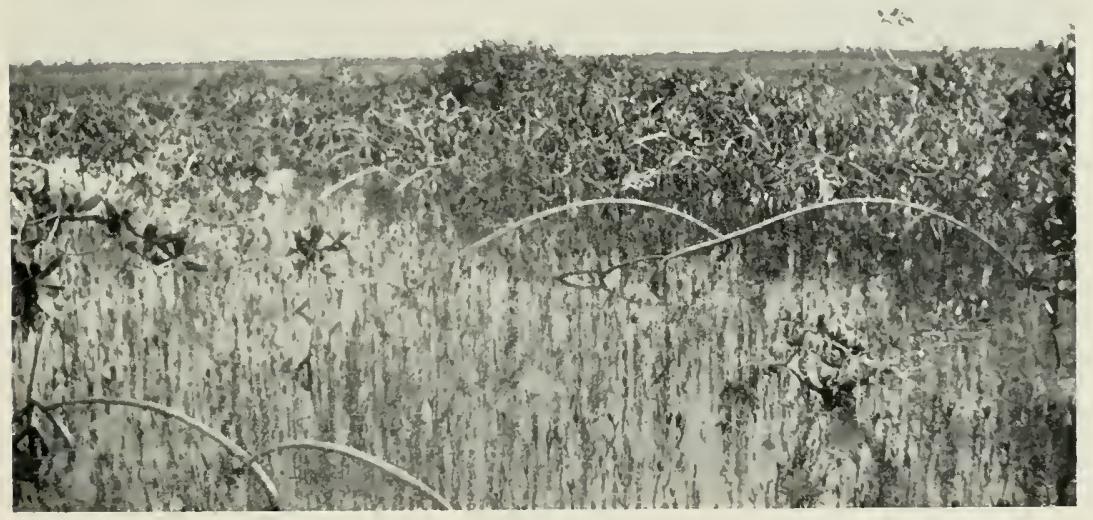

FIG, 2-OWTER EDGE OF MANGROVE SWAMP. GREAT BAHAMA. 



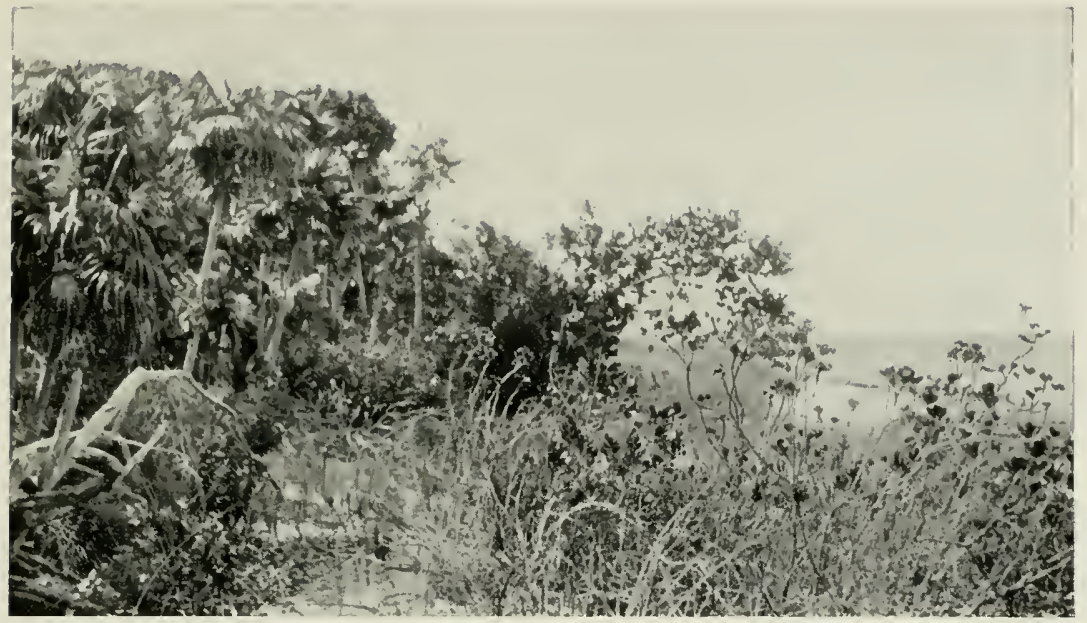

FIG, 3.-CAY VEGETATION, GREAT GUANA CAY.

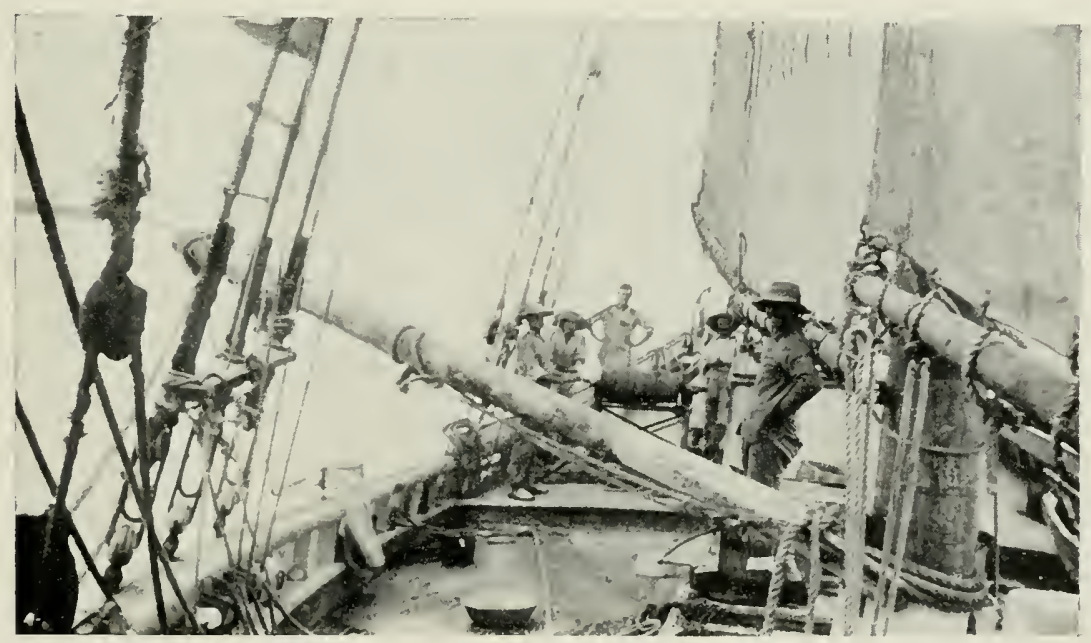

FIF. 4-DREDGING (IPERATIONS ABOARH TIE ' ALBLRY." 




RETURN TO the circulation desk of any University of California Library

or to the

NORTHERN REGIONAL LIBRARY FACILITY

Bldg. 400, Richmond Field Station

University of California

Richmond, CA 94804-4698

ALL BOOKS MAY BE RECALLED AFTER 7 DAYS

- 2-month loans may be renewed by calling (510) 642-6753

-1-year loans may be recharged by bringing books to NRLF

- Renewals and recharges may be made 4 days prior to due date

\section{DUE AS STAMPED BELOW}

JUN 102003

JUN 262007 
Syracuse, N.Y.
Stocktan, Colif. 
